\title{
Analisis Kinerja Perdagangan Indonesia ke Negara Potensial Benua Afrika
}

\author{
Ade Ayu Fleury Amalina ${ }^{1}$, Tanti Novianti ${ }^{2}$, Alla Asmara ${ }^{2}$ \\ Departemen Ilmu Ekonomi \\ Fakultas Ekonomi dan Manajemen, Institut Pertanian Bogor \\ J1. Kamper, Kampus IPB Darmaga \\ Gedung FEM Lt. II, Bogor 16680 \\ *Korespondensi: aa.fleury.amalina@gmail.com
}

[diterima: 1 Juli 2018 - revisi 20 Juli 2018 - diterbitkan daring: 1 Agustus 2018]

\begin{abstract}
ABSTRAK
Liberalisasi perdagangan membuat peluang ekspor antar negara semakin tinggi. Peluang ekspor di negara-negara Afrika dapat dilihat dari tingginya rata-rata pertumbuhan total nilai ekspor dari Indonesia ke Afrika tahun 2011-2016 sebesar 5,886\%. Tujuan penelitian ini adalah mengetahui negara-negara potensial Afrika dengan menggunakan identifikasi nilai dan share ekspor, mengetahui kinerja dan integrasi perdagangan antara Indonesia dengan negara potensial Afrika dengan menggunakan metode RCA, EPD dan IIT. Hasil identifikasi menunjukkan negara Afrika Selatan (Afsel) dengan komoditi HS 71, 15, 40, 87, 84 dan Mesir dengan HS 15, 55, 40, 48, 84 sebagai negara dan komoditi potensial tujuan ekspor Indonesia. Komoditi Indonesia HS 71, 15, dan 40 di Afsel dan di Mesir yaitu HS 15, 55, 40, dan 48 memiliki daya saing kuat. Komoditi Indonesia di pasar Afsel dengan kode HS 15, 84, dan 87 memiliki posisi Falling Star, HS 71 dan 40 memiliki posisi Retreat. Sedangkan di pasar Mesir komoditi HS 15 dan 55 memiliki posisi Falling Star, HS 40, 48, dan 84 memiliki posisi Retreat. Di Afsel, komoditi HS 71, 15, 40 dan HS 87 memiliki integrasi lemah dan HS 50 memiliki integrasi kuat. Sedangkan di Mesir komoditi HS 15, 55, 40, 48, dan 84 memiliki integrasi lemah.
\end{abstract}

Kata kunci: Afrika, RCA, EPD, IIT

\begin{abstract}
Trade liberalization generates higher commodity export opportunities between countries. The export opportunities to the African countries are evidenced by the high average growth of the total export values from Indonesia to Africa in 2011-2016, amounting to $5.886 \%$. The aim of this research is to determine the potential importing African countries through the identification of export value and share, evaluate the performance and trade integration between Indonesia and the African countries through RCA, EPD and IIT methods. The results showed that South Africa with commodities like HS 71, 15, 40, 87 and 84 and Egypt with HS 15, 55, 40, 48 and 84, could be potential export destinations for Indonesia in 2011-2016. The Indonesian HS 71, 15 and 40 commodities in South Africa and Egypt i.e. HS 15, 55, 40, and 48, face tremendous competitivity. The potential Indonesian commodities in the South African market with HS codes of 15, 84, and 87 were considered as Falling Star while HS 71 and 40 were in retreating position. The HS 15 and 55 in the Egyptian market were in the position of Falling Star, with HS 40, 48,
\end{abstract}


and 84 in the Retreat position. In South Africa, the HS commodities 71, 15, 40 and HS 87 were weakly integrated while the HS 50 had a strong integration.

Keywords: African, RCA, EPD, IIT

JEL classification: C23, F10, F13

\section{PENDAHULUAN}

Perdagangan internasional saat ini telah memberikan peran penting dalam perekonomian dunia. Terbukanya suatu negara terhadap perdagangan internasional (liberalisasi perdagangan) membuat peluang ekspor komoditas dari suatu negara ke negara lain semakin tinggi, sehingga dapat meningkatkan pendapatan negara tersebut.

Kinerja merupakan suatu perangkat hasil yang dicapai yang merujuk pada tindakan pencapaian dan pelaksanaan atas sesuatu pekerjaan yang diminta (Stolovitch dan Keeps, 1992). Kinerja ekspor yang baik salah satunya dicerminkan oleh laju pertumbuhan ratarata pertahunnya yang relatif tinggi dibandingkan negara-negara pesaingnya, atau oleh tren pertumbuhan jangka panjangnya yang positif atau meningkat (Kemendag, 2016). Tren pertumbuhan jangka panjang yang meningkat mencerminkan perubahan jangka panjang dari tingkat daya saing produk tersebut didalam perdagangan global (Kemendag, 2016).

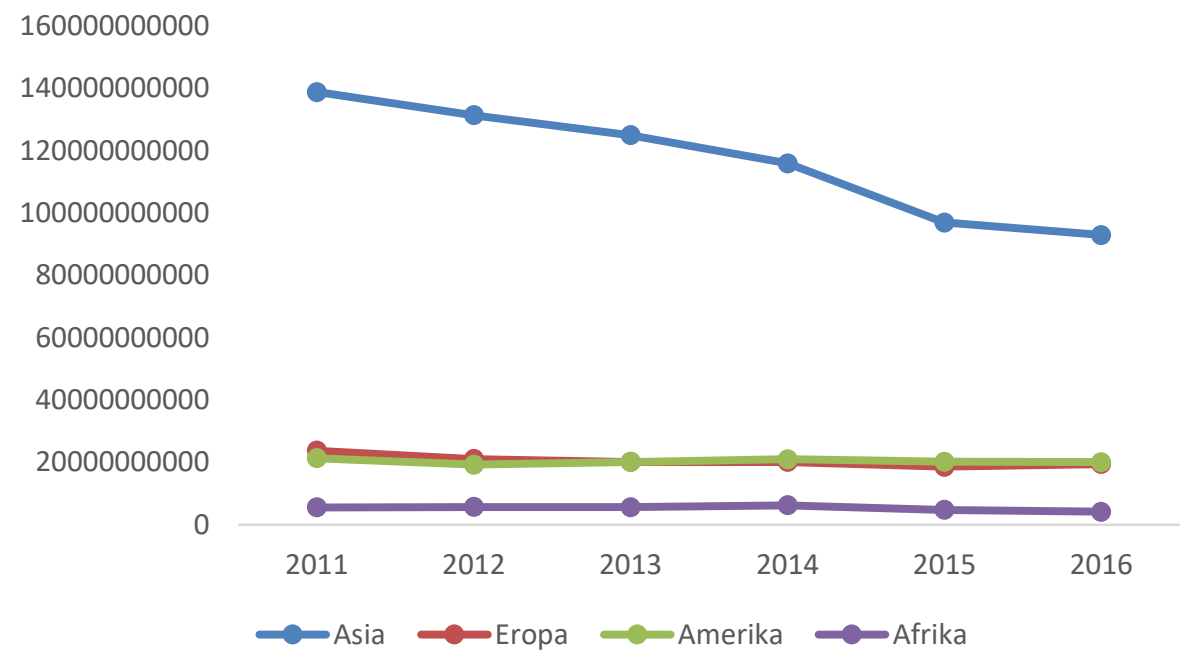

Sumber: WITS (2017)

Gambar 1. Total Nilai Ekspor Indonesia ke Asia, Eropa, Amerika dan Afrika Tahun 2011-2016 (1000 usd)

Berdasarkan Gambar 1, dapat dilihat bahwa diantara Asia, Eropa, Amerika, dan Afrika, rata-rata total nilai ekspor Indonesia ke pasar Asia memiliki nilai tertinggi yaitu berkisar di angka 116 milyar (1000 USD), sedangkan Afrika memiliki nilai terendah yaitu berkisar di angka 5 milyar (1000 USD). 
Tabel 1. Rata-rata Pertumbuhan Total Nilai Ekspor Indonesia ke Asia, Eropa, Amerika, dan Afrika Tahun 2011-2016 (\%)

\begin{tabular}{lccccccc}
\hline \multirow{2}{*}{ Benua } & \multicolumn{9}{c}{ Tahun } & \multicolumn{2}{c}{\begin{tabular}{c} 
Rata-rata \\
Growth \\
\cline { 2 - 7 }
\end{tabular}} & $\mathbf{2 0 1 1}$ & $\mathbf{2 0 1 2}$ & $\mathbf{2 0 1 3}$ & $\mathbf{2 0 1 4}$ & $\mathbf{2 0 1 5}$ & $\mathbf{2 0 1 6}$ & \begin{tabular}{l} 
(\%) \\
\hline Asia
\end{tabular} & 31,577 & $-5,346$ & $-4,907$ & $-7,210$ & $-16,362$ & $-4,162$ & $-1,068$ \\
Eropa & 20,385 & $-11,102$ & $-4,439$ & $-0,169$ & $-7,762$ & 4,683 & 0,266 \\
Amerika & 15,684 & $-9,702$ & 4,615 & 4,238 & $-3,80$ & $-0,748$ & 1,714 \\
Afrika & 58,960 & 2,551 & $-1,682$ & 11,470 & $-24,145$ & $-11,836$ & 5,886 \\
\hline
\end{tabular}

Sumber : WITS (2017)

Namun, berdasarkan Tabel 1. bahwa tingginya rata-rata total nilai ekspor Indonesia ke Asia sejak tahun 2011 hingga 2016 tidak diikuti dengan tingginya rata-rata pertumbuhan nilai ekspor tersebut. Pada tahun 2011 hingga 2016 rata-rata pertumbuhan total nilai ekspor Indonesia ke Asia memiliki nilai yang paling kecil bahkan negatif jika dibandingkan dengan Eropa, Amerika dan Afrika yaitu sebesar $-1,068 \%$. Hal ini menandakan bahwa pasar Asia sudah mulai jenuh bagi ekspor Indonesia. Berbalik dengan Afrika, rata-rata pertumbuhan total nilai ekspor Indonesia ke Afrika memiliki nilai yang positif atau terbesar yaitu 5,886\% yang diikuti oleh Indonesia-Amerika sebesar 1,714\% dan Indonesia-Eropa sebesar 0,266\%. Hal ini menandakan bahwa adanya peluang pasar baru yang potensial di negara-negara Afrika bagi Indonesia untuk dijadikan target pasar.

Berdasarkan paparan diatas maka penelitian Kinerja Perdagangan Indonesia ke Negara Potensial penting untuk dilakukan untuk mengetahui mana saja negara-negara potensial Afrika dan untuk mengetahui kinerja serta integrasi perdagangan antara Indonesia dengan negara-negara potensial Afrika tersebut saat ini.
Berdasarkan uraian diatas maka tujuan penelitian adalah (1) Menganalisis negara-negara potensial Afrika dalam perdagangan Indonesia. (2) Menganalisis kinerja perdagangan Indonesia ke pasar negara-negara potensial di Afrika. (3) Menganalisis integrasi perdagangan produk ekspor potensial Indonesia ke pasar negara potensial di Afrika.

\section{METODE PENELITIAN}

\section{Metode Analisis Data}

Penelitian ini bersifat kuantitatif dan kualitatif dengan periode berlangsung pada tahun 2011 - 2016 dengan data kerat lintang lima komoditi potensial di negara potensial Afrika. Data yang digunakan dalam penelitian ini adalah data sekunder yang diperoleh dari UN Comtrade, World Integrated Trade Solution (WITS), World Bank dan sumber lain yang terkait dengan objek penelitian.

Metode yang digunakan untuk menganalisis tujuan pertama adalah identifikasi berdasarkan rata-rata sektor nilai ekspor dan nilai share ekspor dari Indonesia ke Afrika pada tahun 2011 2016. Kemudian, dalam menjawab 
tujuan kedua menggunakan metode $R C A$ (Revealed Comparative Advantage) dan EPD (Export Product Dynamic), sedangkan tujuan ketiga menggunakan metode Intra Industry Trade (IIT).

\section{Nilai Share Expor}

Share ekspor merupakan salah satu indikator utama yang digunakan dalam menilai (ekspor-impor) kinerja perdagangan, selain laju pertumbuhan (Kemendag, 2016). Negara dengan kinerja ekspor yang baik (berpotensi) dicerminkan oleh rata-rata nilai share ekspor yang relatif tinggi dibandingkan negara-negara pesaingnya. Adapun rumus rata-rata nilai share ekspor adalah sebagai berikut : dimana:

$$
\text { Share Ekspor }=\frac{\Sigma(X t / Y t)}{T}
$$

$X_{t}=$ Nilai ekspor total seluruh komoditi Indonesia ke negara potensial Afrika (US\$)

$Y_{t} \quad=$ Nilai ekspor total seluruh komoditi Indonesia ke benua Afrika (US\$)

$t$ =Tahun ke-n $\quad(\mathrm{n}=$ 2011,2012,..,2016)

$T=$ Banyak tahun analisisis

\section{Revealed Comparative Advantage (RCA)}

Daya saing suatu komoditi dapat diketahui dengan menggunakan analisis Revealed Comparative Advantage (RCA), dimana analisis ini didasarkan pada suatu konsep bahwa perdagangan akan terjadi apabila suatu negara memiliki keunggulan komparatif. Menurut Simatupang (1991), konsep keunggulan komperatif merupakan ukuran daya saing potensial. Artinya, daya saing akan tercapai apabila perekonomian tidak mengalami distorsi.
Dengan kata lain, komoditas yang memiliki keunggulan komparatif dapat dikatakan memiliki efisiensi ekonomi. Variabel yang diukur dalam metode RCA adalah kinerja ekspor suatu komoditi atau produk terhadap total ekspor suatu negara yang kemudian dibandingkan dengan pangsa nilai produk dalam perdagangan dunia. Dalam penelitian ini, kinerja suatu komoditi Indonesia terhadap total ekspor Indonesia ke pasar dunia dibandingkan dengan pangsa nilai ekspor komoditi dunia terhadap total nilai ekspor dunia, dengan menggunakan rumus RCA yaitu:

$$
R C A=\frac{X_{i j} / X_{t}}{W_{i j} / W_{t}} \ldots \ldots \ldots \ldots
$$

dimana:

$$
\begin{array}{ll}
X_{i j} & =\text { Nilai ekspor komoditi } i \\
& \text { Indonesia ke negara } j \text { (US\$) } \\
X_{t} & =\text { Nilai ekspor total seluruh } \\
& \text { komoditi Indonesia ke negara } \\
& \text { potensial Afrika (US\$) } \\
W_{i j} \quad & =\text { Nilai ekspor komoditi } i \text { dunia ke } \\
& \text { negara } j \text { (US\$) } \\
W_{t} \quad & =\text { Nilai ekspor total seluruh } \\
& \text { komoditi dunia ke negara potensial } \\
& \text { Afrika (US\$) } \\
j \quad & =\text { Negara potensial Afrika } \\
i & =\text { Komoditi potensial Indonesia ke } \\
& \text { negara potensial Afrika }
\end{array}
$$

Nilai daya saing dari suatu komoditi memiliki dua kemungkinan, yaitu :

1. Jika nilai $R C A>1$, berarti suatu negara memiliki keunggulan komparatif di atas rata- rata dunia sehingga komoditi tersebut memiliki daya saing kuat.

2. Jika nilai $R C A<1$, berarti suatu negara memiliki keunggulan komparatif di bawah rata-rata dunia sehingga suatu komoditi memiliki daya saing lemah. 


\section{Export Product Dynamic (EPD)}

Export Product Dynamic (EPD) digunakan untuk mengetahui posisi daya saing suatu produk dan melihat suatu produk apakah produk tersebut kompetitif dan memiliki pertumbuhan yang cepat (dinamis) atau tidak. Meskipun suatu produk bukan sebagai komoditi ekspor suatu negara, tetapi apabila memiliki pertumbuhan yang diatas rata-rata atau cepat secara kontinu dalam waktu yang panjang maka komoditi tersebut dapat diperhitungkan sebagai sumber pendapatan suatu negara. Apabila suatu produk dinamis dan mempunyai karakterisktik produksi yang spesifik, maka hal ini akan menjadi informasi penting dalam kesempatan ekspor (hubungan dengan produk). Pada akhirnya, produk yang dinamis tersebut dapat mengatasi berbagai hambatan perdagangan beberapa produk di pasar ekspor akibat semakin terfokusnya negoisasi multilateral atau bilateral.

Export Product Dynamic (EPD) yang digunakan untuk mengetahui posisi daya saing suatu produk memiliki dua komponen yang berkaitan pada matriks EPD yaitu daya tarik pasar dan informasi kekuatan bisnis. Kombinasi kedua komponen ini menghasilkan karakter posisi dari produk yang ingin dianalisis ke dalam empat kategori. Keempat kategori tersebut adalah Rising Star, Falling Star, Lost Opportunity dan Retreat yang dapat dilihat pada Gambar 2 yang berbentuk kuadran dengan sumbu $\mathrm{X}$ menggambarkan peningkatan pangsa pasar ekspor negara tersebut di perdagangan dunia atau daya tarik pasar. Sumbu Y menggambarkan peningkatan pangsa pasar produk tersebut di perdagangan dunia atau informasi kekuatan bisnis.

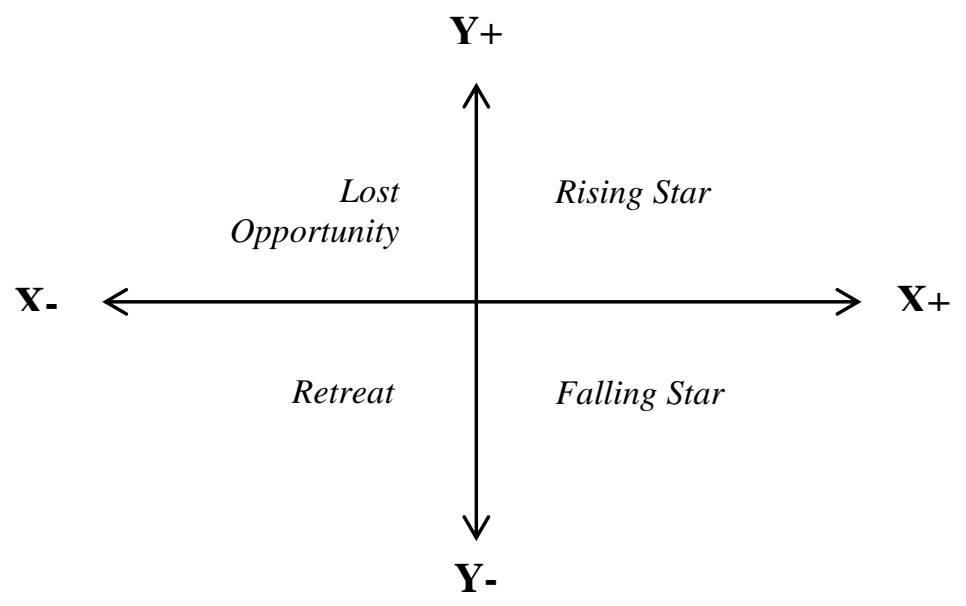

Sumber: Estherhuizen (2006)

Gambar 2. Daya Tarik Pasar dan Kekuatan Bisnis dalam EPD

Adapun rumus yang digunakan dalam perhitungan EPD ini yaitu, sebagai berikut:

Sumbu X : Pertumbuhan pangsa pasar ekspor $i=$

$$
\frac{\sum_{t=1}^{t}\left[\left(\frac{X i j}{W i j}\right)_{t} \times 100 \%-\left(\frac{X i j}{W i j}\right)_{t-1} x 100 \%\right]}{T-1}
$$

Sumbu Y : Pertumbuhan pangsa pasar produk $=$ 


$$
\frac{\sum_{t=1}^{t}\left[\left(\frac{X t}{W t}\right)_{t} \times 100 \%-\left(\frac{X t}{W t}\right)_{t-1} \times 100 \%\right]}{T-1}
$$

dimana :

\begin{tabular}{|c|c|}
\hline$X_{i j}$ & $=$ Nilai ekspor komoditi \\
\hline & Indonesia ke negara $j$ (US\$) \\
\hline$X_{t}$ & $=$ Nilai ekspor total seluruh \\
\hline & $\begin{array}{l}\text { komoditi Indonesia ke negara } \\
\text { potensial Afrika (US\$) }\end{array}$ \\
\hline$W_{i j}$ & $\begin{array}{l}=\text { Nilai ekspor komoditi } i \text { dunia } \\
\text { ke negara } j \text { (US\$) }\end{array}$ \\
\hline$W_{t}$ & $=$ Nilai ekspor total seluruh \\
\hline & $\begin{array}{l}\text { komoditi dunia ke negara } \\
\text { potensial Afrika (US\$) }\end{array}$ \\
\hline$j$ & $=$ Negara potensial Afrika \\
\hline $\mathrm{i}$ & $=$ Komoditi potensial Indonesia \\
\hline & ke negara potensial Afrika \\
\hline$t$ & Tahun \\
\hline & $2011,2012, \ldots, 2016)$ \\
\hline$T$ & $=$ Banyak tahun analisis \\
\hline
\end{tabular}

Posisi Rising Star ditandai dengan perolehan pangsa pasar untuk produkproduk yang berkembang dengan cepat pada negara tersebut. Sementara posisi Lost Opportunity mengindikasikan terjadinya penurunan pangsa pasar pada produk yang dinamis, dimana posisi tersebut merupakan posisi atau kondisi yang paling tidak diinginkan. Hal ini dikarenakan bahwa negara tersebut kehilangan kesempatan pangsa ekspor untuk komoditi yang dinamis di pasar dunia. Posisi Falling Star juga merupakan posisi yang tidak diinginkan, namun tidak seperti posisi Lost Opportunity. Hal ini dikarenakan pada posisi Falling Star pangsa pasarnya meningkat meskipun bukan pada produk yang dinamis di pasar dunia. Sementara itu, pada posisi Retreat mengartikan bahwa produk tersebut tidak diinginkan lagi di pasar. Namun dapat diinginkan kembali jika pergerakannya jauh dari produk stagnan dan bergerak mendekati peningkatan pada produk dinamis.

\section{Teori Perdagangan Intra Industri}

Inter industry trade dan intra industry trade merupakan dua jenis perdagangan internasional. Perdagangan internasional dengan perdagangan komoditas dari sektor/industri yang berbeda disebut dengan Inter Industry Trade. Inter industry trade merupakan perdagangan antara dua industri yang berbeda karena ketersediaan faktor produksi yang juga berbeda secara luas. Inter Industry Trade terjadi berdasarkan teori keunggulan komparatif dimana negara yang memiliki keunggulan komparatif pada komoditas tertentu akan mengekspor komoditas tersebut dan mengimpor komoditas yang negara tersebut tidak memiliki keunggulan komparatif. Keunggulan komparatif, menurut Hecksher dan Ohlin dapat disebabkan oleh perbedaan endowment yang dimiliki suatu negara dimana negara yang memiliki keberlimpahan tenaga kerja akan mengekspor komoditas yang intensif menggunakan tenaga kerja sedangkan negara yang memiliki keberlimpahan barang modal akan mengespor komoditas yang intensif menggunakan barang modal.

Pengertian perdagangan intra industri adalah perdagangan di dalam industri yang sama, hal ini timbul karena kesamaan dalam faktor produksi yang dimiliki antarnegara. Kesamaan tersebut menyebabkan keunggulan komparatif di dalam suatu sektor industri menjadi tidak begitu jelas. Kegiatan perdagangan internasional lebih banyak yang terwujud berupa pertukaran dua arah di dalam industri-industri. Apabila diasumsikan bahwa komoditi yang diperdagangkan di dunia bersifat monopoli maka akan terjadi perdagangan dua arah pada sektor komoditi tersebut. Misalkan pada pertukaran komoditi pakaian dengan pakaian atau bersifat intra industry 
trade, dan perdagangan komoditi pakaian dengan makanan yang bersifat inter industry. Perdagangan yang bersifat intra industry trade tersebut tidak merefleksikan keunggulan komparatif, berbeda dengan inter industry trade. Pentingnya perdagangan tersebut tergantung pada seberapa besar kesamaan antarnegara atas faktor produksi yang dimiliki (Krugman dan Obstfeld 2009).

Menurut Oktaviani dan Novianti (2009), perdagangan intra-industri berpeluang menjadi sumber dominan dari keuntungan perdagangan. Hal ini akan terjadi apabila:

1. Negara-negara yang berdagang sedikit banyak mempunyai kesamaan faktor produksi sehingga kadar perdagangan antar-industri di antara mereka akan berkurang, dan digantikan oleh perdagangan intraindustri.

2. Diferensiasi produk dan skala ekonomis menjadi penting, sehingga keuntungan dari skala yang membesar dan semakin banyaknya pilihan terhitung besar.

Pada perekonomian modern sebagian besar produk yang dihasilkan adalah produk yang terdifferensiasi. Produk yang terdifferensiasi adalah produk yang jenisnya sama atau dihasilkan dalam industri yang sama tetapi berbeda secara kualitas dan atau preferensi.

Perdagangan intra industri menjadi signifikan ketika tarif dan non tarif barrier dihapuskan pada arus perdagangan antarnegara dan adanya perdagangan intra industri akan memperoleh keuntungan dari adanya economies of scale. Dalam hal ini persaingan internasional memaksa setiap perusahaan untuk membatasi model atau tipe produknya agar dapat berkonsentrasi memanfaatkan sumberdayanya untuk menekan biaya produksi per unit sehingga dapat menghasilkan beberapa jenis produk saja tentunya dengan kualitas terbaik dan harga dapat bersaing dari produk lainnya. Disisi lain kebutuhan konsumen akan produk atau tipe lain dipenuhi melalui impor dari negara lain.

Perdagangan intra-industri memegang peranan besar khususnya di dalam perdagangan barang-barang manufaktur di antara negara-negara industri maju yang pada dasarnya mendominasi perdagangan dunia. Perdagangan intra-industri akan cenderung terjadi di antara negaranegara yang mempunyai kesamaan dalam nisbah moda tenaga kerja dan keahlian tenaga kerja. Artinya, perdagangan intra-industri akan menjadi penting bagi negara-negara yang tingkat kemajuan pembangunan ekonominya kurang lebih setara. Pada dasarnya, besar kecilnya volume perdagangan intraindustri atau peforma ekpor suatu negara dapat diukur berdasarkan indeks perdagangan intra-industri atau dengan analisis Intra Indutry Trade (IIT). Intra Industry Trade index (IIT index) digunakan untuk menganalisis tingkat integrasi dalam suatu kawasan tertentu. Integrasi yang tinggi menunjukkan kedekatan perdagangan di antara negaranegara di kawasan tersebut. Intra Industry Trade (IIT) index yang umum digunakan adalah Grubel-Lloyd Index dengan rumus:

$$
I I T_{i, j k}=1-\frac{\left|X_{i, j k}-M_{i, j k}\right|}{X_{i, j k}+M_{i, j k}} x 100
$$

dimana:

$$
\begin{aligned}
\mathrm{IIT}_{\mathrm{i}, \mathrm{jk}}= & \text { indeks perdagangan intra- } \\
& \text { industri } \\
\mathrm{X}_{\mathrm{i}, \mathrm{jk}}= & \text { nilai ekspor komoditas } i \text { dari } \\
& \text { negara } j \text { ke negara } k \\
\mathrm{M}_{\mathrm{i}, \mathrm{jk}}= & \text { nilai impor komoditas } i \text { dari } \\
& \text { negara } j \text { ke negara } k
\end{aligned}
$$


Nilai Grubel Lloyd Index berkisar antara 0 sampai 100. Jika jumlah yang diekspor sama dengan jumlah yang diimpor untuk suatu produk, maka indeksnya akan bernilai 100. Sebaliknya apabila perdagangan suatu negara hanya melibatkan satu pihak saja (ekspor atau impor saja) maka nilai indeksnya adalah 0 .

Tabel 2. Klasifikasi Intra Industry Trade (IIT)

\begin{tabular}{cc}
\hline Intra Industry Trade (IIT) & Klasifikasi \\
\hline$*$ & Tidak terdapat aliran perdagangan \\
0.00 & Tidak ada integrasi (perdagangan satu arah) \\
$>0.00-24.99$ & Integrasi lemah \\
$25.00-49.99$ & Integrasi sedang \\
$50.00-74.99$ & Integrasi kuat \\
$75.00-99.99$ & Integrasi sangat kuat
\end{tabular}

Sumber: Austria (2004)

\section{HASIL DAN PEMBAHASAN}

\section{Analisis Negara-negara Potensial Afrika dalam Perdagangan Indonesia}

Negara-negara potensial Afrika dalam perdagangan Indonesia dapat dianalisis atau ditentukan dengan menggunakan beberapa indikator. Indikator yang digunakan dalam penelitian ini yaitu nilai ekpor dan share ekspor antara perdagangan Indonesia ke Afrika. Negara-negara Afrika dalam perdagangan Indonesia dapat dikatakan potensial jika nilai ekspor dan share ekspor Indonesia ke negara Afrika tinggi atau di atas rata-rata jika dibandingkan dengan negara Afrika lainnya.

Dalam penelitian ini, negara potensial Afrika sebagai negara tujuan ekspor Indonesia dapat ditentukan dari nilai ekspor dan share ekspor Indonesia ke Afrika yang memiliki nilai tertinggi pada tahun 2011 - 2016. Tabel 2, menunjukkan negara yang memiliki nilai perdagangan (ekspor) dan share ekspor Indonesia di Afrika diatas rata-rata diantara negara Afrika lainnya.

Tabel 2. Total Nilai Ekspor Indonesia dan Nilai Share Ekspor Indonesia Tertinggi ke Negara Potensial Afrika Tahun 2011-2016

\begin{tabular}{lcc}
\hline Negara Tujuan & $\begin{array}{c}\text { Rata-rata Nilai Ekspor Indonesia } \\
\text { (1 juta USD) }\end{array}$ & $\begin{array}{c}\text { Rata-rata Nilai Share Ekspor } \\
\text { Indonesia }\end{array}$ \\
\hline Mesir & 1.193 .735 & 0,227 \\
Afrika Selatan & 1.195 .323 & 0,220 \\
Nigeria & 473.736 & 0,088 \\
Djibouti & 256.539 & 0,048 \\
Kenya & 228.350 & 0,043 \\
Tanzania & 216.472 & 0,041 \\
\hline
\end{tabular}




\begin{tabular}{lll}
\hline Algeria & 182.889 & 0,034 \\
Ghana & 175.058 & 0,033 \\
Benin & 144.232 & 0,028 \\
Angola & 132.373 & 0,024 \\
\hline
\end{tabular}

Sumber: diolah dari WITS (2017)

Menurut WITS (2017), nilai ratarata ekspor Indonesia ke Afrika yaitu sebesar 100.586 (1 juta USD) dari 53 negara di Afrika yang melakukan hubungan perdagangan dengan Indonesia. Berdasarkan Tabel 2 maka didapat sepuluh negara prospektif tujuan Afrika secara berurutan, yaitu Afrika Selatan, Mesir, Nigeria, Djibouti, Kenya, Tanzania, Algeria, Ghana, Benin, dan Angola. Namun, dari kesepuluh negara tersebut, Afrika Selatan dan Mesir merupakan negara tujuan ekpor yang memiliki rata-rata nilai yang jauh lebih unggul jika dibandingkan dengan delapan negara Afrika lainnya. Rata-rata nilai ekspor dari Indonesia ke Afrika Selatan yaitu sebesar 1.195.323.048 (1000USD) dan diikuti oleh Mesir sebesar 1.193.735.048 (1000USD). Sama halnya dengan rata-rata nilai ekspor, rata-rata nilai share ekspor Mesir dan Afrika Selatan pun memiliki nilai yang jauh lebih besar jika dibandingkan dengan negara-negara lainnya yaitu sebesar 0.227 dan 0.220 . Hal inilah yang membuat penelitian ini hanya fokus pada ruang lingkup kedua negara tersebut, yaitu Afrika Selatan dan Mesir.

Dalam mengidentifikasi komoditi potensial di kedua negara tersebut, peneliti mengambil lima komoditi terbesar berdasarkan rata-rata nilai ekspor komoditi potensial tertinggi di Afrika Selatan dan Mesir dalam perdagangan Indonesia dari tahun 20112016.

Tabel 3. Rata-Rata Nilai Ekspor Komoditi Potensial Tertinggi di Afrika Selatan dan Mesir dalam Perdagangan Indonesia, Tahun 2011-2016 (1 Juta USD)

\begin{tabular}{cccc}
\hline \multicolumn{2}{c}{ Afrika Selatan } & \multicolumn{2}{c}{ Mesir } \\
\hline HS & Rata-Rata Nilai Ekspor & HS & Rata-Rata Nilai Ekspor \\
\hline 71 & 402.582 & 15 & 402.582 \\
15 & 232.535 & 55 & 232.535 \\
40 & 83.067 & 40 & 83.067 \\
87 & 73.732 & 48 & 73.732 \\
84 & 44.610 & 84 & 44.610 \\
\hline
\end{tabular}

Sumber: WITS (2017) diolah

Keterangan :

HS 71:Natural or cultured pearls, precious or semi-precious stones, preciousmetals, metals clad with precious metal and articles thereof; immitation jewellery; coin

HS 15 : Animal or Vegetables fats and oil and their cleavage products; prepared edible fats; animal or vegetables waxes

HS 55 : Man-made staple fibres

HS $40:$ Rubber and articles thereof

HS 48 : Paper and paperboard; articles of paper pulp, of paper or of paperboard

HS 84 : Nuclear reactors, boilers, machinery and mechanical appliances; parts thereof

HS 87 :Vehicles other than railway or tramway rolling-stock, and parts and accessories thereof 
Tabel 3, menunjukkan komoditi potensial tertinggi yang memiliki nilai ekspor Indonesia ke Afrika Selatan diatas rata-rata diantara komoditi lainnya di Afrika Selatan. Berdasarkan World Integrated Trade Solution (2017), nilai rata-rata ekspor komoditi dari seluruh komoditi Indonesia ke Afrika Selatan yaitu sebesar 12.582 ( 1 juta USD) dari 95 komoditi Afrika Selatan yang melakukan hubungan perdagangan dengan Indonesia. Top lima komoditi tersebut secara berurutan, yaitu: HS 71, 15, 40, 87 dan 84. Komoditi HS 71 yang memiliki rata-rata nilai ekspor tertinggi sebesar 402.582 (1 juta USD) menyumbang nilai ekspor hingga $33 \%$ dari rata-rata total ekspor Indonesia ke Afrika Selatan pada tahun 2011-2016. Diikuti oleh HS 15 sebesar 19,5\%, HS 40 sebesar $6,9 \%$, HS 87 sebesar $6,1 \%$ dan HS 84 sebesar 3,7\%. Sedangkan, komoditi potensial tertinggi yang memiliki nilai ekspor Indonesia ke Mesir diatas rata-rata sebesar 13.565 (1 juta USD) dari 88 komoditi Mesir yang melakukan hubungan perdagangan dengan Indonesia, yaitu : HS 15, 55, 40, 48, dan 84. Komoditi HS 15 yang memiliki rata-rata nilai ekspor tertinggi sebesar 702.675 (1 juta USD) menyumbang nilai ekspor hingga $58 \%$ dari rata-rata total ekspor Indonesia ke Mesir pada tahun 2011-2016. Diikuti oleh HS 55 sebesar 8,1\%, HS 40 sebesar 4,3\%, HS 48 sebesar 3,6\% dan HS 84 sebesar $2,7 \%$. Berdasarkan pembahasan di atas, maka dalam penelitian ini akan fokus dalam menggunakan dua negara potensial Afrika Selatan dan Mesir, masing-masing dengan lima komoditi potensial Indonesia di kedua negara tersebut, yaitu HS 71, 15, 40, 87, dan HS 84 (Afrika Selatan) dan HS 15, 55, 40, 48, dan HS 84 (Mesir).Analisis Kinerja Perdagangan Indonesia ke Pasar Negara Mesir dan Afrika Selatan.

\section{Analisis Kekuatan Daya Saing Komoditi Potensial Indonesia di Mesir dan Afrika Selatan}

Daya saing suatu komoditi yang didasarkan pada keunggulan komparatif suatu komoditi dari suatu negara dapat ditentukan dengan menggunakan metode Revealed Comparative Advantage (RCA), dimana variabel yang diukur dalam metode ini adalah kinerja ekspor. Jika nilai RCA lebih besar dari satu, maka suatu negara memiliki kinerja ekspor yang baik dan memiliki keunggulan komparatif di atas rata-rata dunia atas komoditinya sehingga komoditi tersebut memiliki daya saing kuat. Hal ini dapat dipertahankan negara tersebut untuk tetap beriorentasi ekspor ke negara tujuan. Jika nilai RCA lebih kecil dari satu maka suatu negara memiliki kinerja ekspor yang buruk dan memiliki keunggulan komparatif di bawah rata-rata dunia atau dengan kata lain tidak memiliki keunggulan komparatif atas komoditinya, sehingga suatu komoditi memiliki daya saing lemah. Tabel 4 adalah hasil perhitungan nilai-nilai RCA. 
Tabel 4. Hasil Perhitungan Nilai RCA Tertinggi Komoditi Potensial Indonesia di Afrika Selatan Tahun $2011-2016$

\begin{tabular}{llrrrrrrrc}
\hline \multirow{2}{*}{ HS } & \multicolumn{1}{c}{ Nama Produk } & \multicolumn{7}{c}{ Nilai RCA } & Rata-Rata \\
\cline { 2 - 7 } & $\mathbf{2 0 1 1}$ & $\mathbf{2 0 1 2}$ & $\mathbf{2 0 1 3}$ & $\mathbf{2 0 1 4}$ & $\mathbf{2 0 1 5}$ & $\mathbf{2 0 1 6}$ & Nilai RCA \\
\hline $\mathbf{7 1}$ & $\begin{array}{l}\text { Natural/cultured pearls, } \\
\text { prec stone }\end{array}$ & 3,02 & 3,58 & 3,55 & 9,58 & 0,44 & 2,55 & 3,79 \\
$\mathbf{1 5}$ & $\begin{array}{l}\text { Animal/veg fats \& oils \& } \\
\text { their clea }\end{array}$ & 15,35 & 13,64 & 23,56 & 27,40 & 40,01 & 29,62 & 24,93 \\
$\mathbf{4 0}$ & $\begin{array}{l}\text { Rubber and articles } \\
\text { thereof. }\end{array}$ & 6,23 & 4,30 & 5,18 & 3,08 & 4,41 & 3,04 & 4,37 \\
$\mathbf{8 4}$ & $\begin{array}{l}\text { Nuclear reactors, boilers, } \\
\text { mchy \& m }\end{array}$ & 0,23 & 0,25 & 0,31 & 0,20 & 0,35 & 0,28 & 0,27 \\
$\mathbf{8 7}$ & $\begin{array}{l}\text { Vehicles o/t railw/tramw } \\
\text { roll-stock }\end{array}$ & 0,47 & 0,40 & 0,55 & 0,34 & 0,63 & 0,64 & 0,51 \\
\hline
\end{tabular}

Sumber: diolah dari WITS (2017)

Berdasarkan perhitungan nilai RCA tertinggi komoditi negara tujuan ekspor Afrika Selatan pada Tabel 4, diperoleh bahwa hanya komoditi dengan kode HS 71, 15, dan 40 yang memiliki daya saing kuat selama periode 20112016. Hal ini terlihat dari nilai RCA yang lebih besar dari satu; dengan kisaran nilai 3,79-24,93.

Meskipun komoditi dengan kode HS 71, 15, dan 40 memiliki daya saing yang kuat dengan nilai RCA yang selalu lebih besar dari satu, namun nilai RCA cenderung berfluktuasi. Hal ini disebabkan oleh nilai ekspor yang mengalami tren fluktuatif. Dilihat dari Tabel 4, kode HS 15 memiliki nilai ratarata RCA yang paling tinggi diantara komoditi ekspor lainnya, yaitu sebesar 24,93. Hal ini menunjukkan bahwa komoditi tersebut memiliki keunggulan komparatif yang tinggi di pasar Afrika Selatan. Selanjutnya, diikuti oleh HS 40 sebesar 4,37 dan HS 71 sebesar 3,79. Sebaliknya, HS 87 dan 84 memiliki nilai rata-rata RCA yang paling kecil diantara komoditi ekspor lainnya atau kurang dari satu yaitu sebesar 0,51 dan 0,27 . Hal ini menandakan bahwa komoditi tersebut tidak memiliki keunggulan komparatif di pasar Afrika Selatan.

Tabel 5. Hasil Perhitungan Nilai RCA Komoditi Potensial Indonesia di Mesir Tahun $2011-2016$

\begin{tabular}{llllccccc}
\hline \multirow{2}{*}{ HS } & \multicolumn{1}{c}{ Nama Produk } & \multicolumn{9}{c}{ Nilai RCA } & Rata-Rata \\
\cline { 3 - 7 } & $\mathbf{2 0 1 1}$ & $\mathbf{2 0 1 2}$ & $\mathbf{2 0 1 3}$ & $\mathbf{2 0 1 4}$ & $\mathbf{2 0 1 5}$ & $\mathbf{2 0 1 6}$ & Nilai RCA \\
\hline $\mathbf{1 5}$ & $\begin{array}{l}\text { Animal/veg fats \& oils \& } \\
\text { their clea }\end{array}$ & 12,44 & 14,09 & 16,76 & 25,01 & 26,13 & 20,92 & 19,23 \\
$\mathbf{5 5}$ & Man-made staple fibres. & 5,00 & 7,45 & 8,94 & 8,57 & 9,52 & 10,44 & 8,32 \\
$\mathbf{4 0}$ & $\begin{array}{l}\text { Rubber and articles } \\
\text { thereof. } 3,84\end{array}$ & 3,74 & 3,45 & 3,21 & 3,24 & 3,88 & 3.56 \\
$\mathbf{4 8}$ & $\begin{array}{l}\text { Paper \& paperboard; art of } \\
\text { paper pu }\end{array}$ & 2,31 & 3,55 & 2,16 & 1,80 & 1,93 & 2,24 & 2.33 \\
$\mathbf{8 4}$ & $\begin{array}{l}\text { Nuclear reactors, boilers, } \\
\text { mchy \& m }\end{array}$ & 0,15 & 0,26 & 0,28 & 0,35 & 0,21 & 0,12 & 0.23 \\
\hline
\end{tabular}

Sumber: diolah dari WITS (2017) 

Berdasarkan perhitungan nilai RCA top five komoditi negara tujuan ekspor Mesir pada Tabel 5, diperoleh bahwa hampir semua komoditi diatas memiliki daya saing kuat selama periode 2011-2016. Komoditi tersebut yaitu HS 15, 55, 40, dan 48. Hal ini terlihat dari nilai RCA yang lebih besar dari satu; dengan kisaran nilai 2,33-19,23.

Meskipun komoditi dengan kode HS 15, 55, 40, dan 48 memiliki daya saing yang kuat dengan nilai RCA yang selalu lebih besar dari satu, namun nilai RCA cenderung berfluktuasi. Hal ini disebabkan oleh nilai ekspor yang mengalami tren fluktuatif. Dilihat dari Tabel 5, kode HS 15 memiliki nilai ratarata RCA yang paling tinggi diantara komoditi ekspor lainnya, yaitu sebesar 19,23. Hal ini menunjukkan bahwa komoditi tersebut memiliki keunggulan komparatif yang tinggi di pasar Mesir. Selanjutnya, diikuti oleh HS 55 sebesar 8,32, HS 40 sebesar 3,56 dan HS 48 yaitu sebesar 2,33 . Sebaliknya, komoditi HS 84 memiliki nilai rata-rata RCA yang paling kecil diantara komoditi ekspor lainnya atau kurang dari satu yaitu sebesar 0,23. Hal ini menandakan bahwa komoditi tersebut tidak memiliki keunggulan komparatif di pasar Mesir.

\section{Analisis Posisi Daya Saing Komoditi Potensial Indonesia di Afrika Selatan dan Mesir}

Daya saing suatu komoditi yang didasarkan pada keunggulan kompetitif suatu komoditi di negara tujuan, dapat dilihat dari posisi pasar yang diperoleh dengan menggunakan metode Export Product Dynamic (EPD).

Metode ini juga digunakan untuk melihat apakah ekspor komoditi tersebut memiliki pertumbuhan yang cepat (dinamis) atau tidak. Jika suatu komoditi memiliki pertumbuhan di atas rata-rata atau cepat (dinamis) secara kontinu dalam waktu yang panjang, maka komoditi tersebut dapat diperhitungkan sebagai sumber pendapatan ekspor negara.

Tabel 6. Hasil Perhitungan Nilai EPD Komoditi Potensial Indonesia di Afrika Selatan Tahun 2011 - 2016

\begin{tabular}{clccc}
\hline HS & \multicolumn{1}{c}{ Nama Produk } & Growth x & Growth y & EPD \\
\hline 71 & Natural/cultured pearls, prec stone & $-0,0022$ & $-0,00037$ & Reatret \\
15 & Animal/veg fats \& oils \& their clea & 0,0275 & $-0,00037$ & Falling Star \\
40 & Rubber and articles thereof. & $-0,0097$ & $-0,00037$ & Reatret \\
84 & Nuclear reactors, boilers, mchy \& m & 0,0002 & $-0,00037$ & Falling Star \\
87 & Vehicles o/t railw/tramw roll-stock & $1,05 \mathrm{E}-05$ & $-0,00037$ & Falling Star \\
\hline
\end{tabular}
Sumber: diolah dari WITS (2017)

Berdasarkan hasil perhitungan nilai EPD pada Tabel 6, komoditi dengan kode HS 15, 84 dan 87 di pasar negara tujuan yaitu Afrika Selatan berada di posisi pasar Falling Star. Hal ini menunjukkan bahwa selama periode 2011-2016, komoditi tersebut di pasar Afrika Selatan memiliki pangsa pasar yang meningkat meskipun bukan pada produk yang dinamis di pasar dunia.

Berbeda dengan HS 15, 84 dan 87 diatas, komoditi dengan HS 71 dan 40 berada di posisi Retreat. Ini mengindikasikan bahwa produk tersebut tidak diinginkan lagi di pasar dikarenakan terjadinya penurunan 
pangsa pasar ekspor Indonesia pada komoditi tersebut di pasar yang tidak dinamis. Namun dapat diinginkan kembali jika pergerakannya jauh dari produk stagnan dan bergerak mendekati peningkatan pada produk dinamis.

Tabel 7. Hasil Perhitungan Nilai EPD Komoditi Potensial Indonesia di Mesir Tahun $2011-2016$

\begin{tabular}{clccc}
\hline HS & \multicolumn{1}{c}{ Nama Produk } & Growth x & Growth y & EPD \\
\hline 15 & Animal/veg fats \& oils \& their clea & 0,0250 & $-0,00068$ & Falling Star \\
55 & Man-made staple fibres. & 0,0181 & $-0,00068$ & Falling Star \\
40 & Rubber and articles thereof. & $-0,0024$ & $-0,00068$ & Reatret \\
48 & Paper \& paperboard; art of paper pu & $-0,0018$ & $-0,00068$ & Reatret \\
84 & Nuclear reactors, boilers, mchy \& m & $-0,0002$ & $-0,00068$ & Reatret
\end{tabular}
Sumber: diolah dari WITS (2017)

Berdasarkan hasil perhitungan nilai EPD pada Tabel 7, komoditi dengan kode HS 15 dan 55 di pasar negara tujuan yaitu Mesir berada di posisi pasar Falling Star. Hal ini menunjukkan bahwa selama periode 2011-2016, komoditi tersebut di pasar Mesir memiliki pangsa pasar yang meningkat meskipun bukan pada produk yang dinamis di pasar dunia.

Berbeda dengan HS 15 dan 55 diatas, komoditi dengan HS 40, 48 dan 84 berada di posisi Retreat. Ini mengindikasikan bahwa produk tersebut tidak diinginkan lagi di pasar dikarenakan terjadinya penurunan pangsa pasar ekspor Indonesia pada komoditi tersebut di pasar yang tidak dinamis. Namun dapat diinginkan kembali jika pergerakannya jauh dari produk stagnan dan bergerak mendekati peningkatan pada produk dinamis.

\section{Analisis Integrasi Perdagangan}

Derajat integrasi dalam tiap-tiap komoditi dapat diukur dengan IntraIndustry Trade index (IIT). Besarnya IIT menggambarkan besarnya perdagangan intraindustri, yakni besarnya ekspor impor komoditi-komoditi dari industri yang sama. Dengan demikian, untuk mengukur derajat integrasi pada setiap komoditi di Mesir dan Afrika Selatan dapat dilakukan dengan pengukuran IIT.

Tabel 8. Hasil Perhitungan Nilai IIT Komoditi Potensial Indonesia di Afrika Selatan Tahun 2011 - 2016

\begin{tabular}{|c|c|c|c|c|c|c|c|c|}
\hline \multirow{2}{*}{ HS } & \multirow{2}{*}{ Product Name } & \multicolumn{6}{|c|}{ Tahun } & \multirow{2}{*}{$\begin{array}{l}\text { Rata- } \\
\text { Rata }\end{array}$} \\
\hline & & 2011 & 2012 & 2013 & 2014 & 2015 & 2016 & \\
\hline 71 & $\begin{array}{l}\text { Natural/cultured pearls, prec } \\
\text { stone }\end{array}$ & 0,000 & 0,001 & 0,000 & 0,000 & 0,041 & 39,051 & 6,515 \\
\hline 15 & $\begin{array}{l}\text { Animal/veg fats \& oils \& } \\
\text { their clea }\end{array}$ & 0,327 & 0,082 & 0,003 & 0,003 & 0,058 & 0,008 & 0,080 \\
\hline 40 & Rubber and articles thereof. & 0,150 & 0,512 & 0,777 & 0,394 & 0,318 & 4,686 & 1,139 \\
\hline
\end{tabular}




\begin{tabular}{lllllllll}
\hline $\mathbf{8 4}$ & $\begin{array}{l}\text { Nuclear reactors, boilers, } \\
\text { mchy \& m }\end{array}$ & 63,886 & 54,714 & 35,806 & 68,310 & 67,669 & 34,386 & 63,477 \\
$\mathbf{8 7}$ & $\begin{array}{l}\text { Vehicles o/t railw/tramw } \\
\text { roll-stock }\end{array}$ & 0,934 & 9,649 & 4,963 & 10,272 & 3,518 & 1,244 & 5.992 \\
\hline Sumber: diolah dari WITS (2017) & & & & & & & & \\
\hline
\end{tabular}

Sumber: diolah dari WITS (2017)

Berdasarkan hasil perhitungan pada tabel 8, dapat dikatakan bahwa hampir semua komoditi potensial Indonesia di Afrika Selatan memiliki nilai rata-rata dengan klasifikasi integrasi lemah pada tahun 2011-2016. Komoditi tersebut yaitu komoditi dengan kode HS 71, 15, 40 dan HS 87. Hal ini dapat dilihat pada nilai IIT yang lebih dari 0 hingga 24,99. Namun, terdapat satu komoditi yang memiliki nilai rata-rata dengan klasifikasi integrasi kuat yaitu komoditi dengan kode HS 84. Hal ini dapat dilihat pada nilai IIT dari 50 hingga 74,99 yaitu sebesar 63,47.

Tabel 9. Hasil Perhitungan Nilai IIT Komoditi Potensial Indonesia di Mesir Tahun 2011 $-2016$

\begin{tabular}{|c|c|c|c|c|c|c|c|c|}
\hline \multirow[b]{2}{*}{ HS } & \multirow{2}{*}{ Product Name } & \multicolumn{6}{|c|}{ Tahun } & \multirow{2}{*}{$\begin{array}{l}\text { Rata- } \\
\text { rata }\end{array}$} \\
\hline & & 2011 & 2012 & 2013 & 2014 & 2015 & 2016 & \\
\hline 15 & $\begin{array}{l}\text { Animal/veg fats \& oils \& } \\
\text { their clea }\end{array}$ & 0,009 & 0,093 & 0,047 & 0,024 & 0,051 & 0,161 & 0,064 \\
\hline 55 & Man-made staple fibres. & 8,317 & 0,916 & 0,033 & 0,000 & 0,000 & 0,000 & 1,544 \\
\hline 40 & Rubber and articles thereof. & 7,870 & 0,057 & 0,323 & 0,006 & 0,852 & 0,493 & 1,60 \\
\hline 48 & $\begin{array}{l}\text { Paper \& paperboard; art of } \\
\text { paper pu }\end{array}$ & 0,000 & 0,000 & 0,000 & 0,000 & 0,000 & 0,008 & 0.001 \\
\hline 84 & $\begin{array}{l}\text { Nuclear reactors, boilers, } \\
\text { mchy \& m }\end{array}$ & 77,49 & 8,947 & 0,717 & 2,082 & 0,718 & 4,849 & 15,80 \\
\hline
\end{tabular}

Sumber: diolah dari WITS (2017)

Berdasarkan hasil perhitungan pada tabel 9, dapat dikatakan bahwa semua komoditi potensial Indonesia di Mesir memiliki nilai rata-rata dengan klasifikasi integrasi lemah pada tahun 2011-2016. Komoditi tersebut yaitu komoditi dengan kode HS 15, 55, 40, 48 dan HS 84. Hal ini dapat dilihat pada nilai IIT yang lebih dari 0 hingga 24,99.

\section{KESIMPULAN}

1. Negara potensial Afrika sebagai negara tujuan ekspor Indonesia adalah negara Afrika Selatan dan Mesir pada periode 2011-2016. Dimana, lima komoditi potensial
Indonesia di Afrika Selatan yaitu komoditi dengan kode HS 71, 15, 40, 87 dan 84. Sedangkan lima komoditi potensial Indonesia di Mesir yaitu komoditi dengan kode HS 15, 55, 40, 48, dan 84.

2. Beberapa komoditi potensial Indonesia di Afrika Selatan memiliki daya saing yang kuat selama periode 2011-2016 dengan nilai RCA yang lebih dari satu. Komoditi tersebut yaitu komoditi dengan kode HS 71, 15, dan 40. Sedangkan, komoditi potensial Indonesia di Mesir yang memiliki daya saing kuat selama periode 2011-2016 yaitu komoditi dengan kode HS 15, 55, 40, dan 48. 
Pada komoditi potensial Indonesia di pasar Afrika Selatan, komoditi dengan kode HS 15, 84, dan 87 berada pada posisi Falling Star, HS 71 dan 40 berada pada posisi Retreat. Sedangkan, pada komoditi potensial Indonesia di pasar Mesir komoditi dengan kode HS 15 dan 55 berada pada posisi Falling Star, HS 40, 48, dan 84 berada pada posisi Retreat.

3. Hampir semua komoditi potensial Indonesia di Afrika Selatan memiliki klasifikasi integrasi lemah dengan nilai IIT yang lebih dari 0 hingga 24,99 pada periode 2011-2016. Komoditi tersebut yaitu komoditi dengan kode HS 71, 15, 40 dan HS 87. Sedangkan, komoditi dengan kode HS 50 memiliki klasifikasi integrasi kuat dengan nilai IIT dari 50 hingga 74,99 pada periode 20112016. Hampir sama halnya dengan negara tujuan Afrika Selatan, komoditi potensial Indonesia di Mesir pun memiliki klasifikasi integrasi lemah bahkan pada keseluruhan lima komoditi potensialnya yaitu HS 15 , 55, 40, 48, dan 84 .

\section{SARAN}

1. Berdasarkan hasil dari nilai Revealed Comparatif Advantage komoditi potensial Indonesia di Afrika Selatan yaitu HS 71,15,40 dan komoditi potensial Indonesia di Mesir yaitu HS 15,55,40, dan 48, maka perlu dilakukan upaya-upaya mempertahankan nilai daya saing yang tinggi di negara tujuan ekspor tersebut. Salah satunya yaitu tetap menjaga dan memelihara efisiensi serta kualitas dari proses penghasil produk maupun sistem pelayanan yang diberikan untuk senantiasa dapat memuaskan konsumen. Hal ini dilakukan agar komoditi tersebut tetap mampu menguasai perdagangan di pasar internasional.

2. Berdasarkan hasil dari nilai Export Product Dynamic, maka perlu dilakukan upaya-upaya peningkatan pangsa produk ekspor yang dinamis pada komoditi HS 15, 84, dan 87 Indonesia di Afrika Selatan dan HS 15 dan 55 di Mesir, yang telah mengalami kondisi falling star. Demikian pula perlu dilakukan upaya-upaya yang lebih keras lagi pada komoditi HS 71 dan 40 Indonesia di Afrika Selatan dan HS 40, 84, dan 48 di Mesir yang mengalami kondisi retreat agar pangsa pasarnya semakin meningkat dan menjadi dinamis. Dari sisi pengusaha, hal tersebut dapat dilakukan dengan cara meningkatkan efisiensi dan kesesuaian produk, penciptaan sistem yang dapat meningkatkan kekuatan harga, kualitas produk serta distribusi. Dari sisi pemerintah Indonesia, dapat dilakukan dengan cara mengefektifkan fungsi pemerintah dengan mengurangi hambatanhambatan yang dirasakan pelaku bisnis Indonesia seperti adanya pungli yang menyebabkan high cost economy dan sulitnya perijinan pemerintah pusat dan daerah yang dapat menyebabkan bisnis sulit tumbuh.

\section{DAFTAR PUSTAKA}

Austria, M. 2004. The Pattern of IntraASEAN Trade in Priority Good Sectors. ASEAN Sekretariat. Jakarta.

Esterhuizen, D. 2006. An Evaluation of The Competitiveness of The South African Agribusiness Sector. University of Pretoria.

Firdaus, A.H. 2010. Kinerja Perdagangan dan Dampak Free 
Trade Area (FTA) ASEAN Plus Three terhadap Perekonomian Indonesia. [Tesis]. Program Pascasarjana, Institut Pertanian Bogor, Bogor.

Kemendag (Kementerian Perdagangan). 2016. Direktorat Jenderal Perdagangan Luar Negeri. www.kemendag.go.id [Agustus 2016].

Krugman P.R., Obstfeld, M. 2009. International Economics: Theory \& Policy. Clinton D, editor. Boston (US): The AddisonWesley. Ed ke-8.

Oktaviani R., Novianti T. 2009. Teori Perdagangan Internasional dan Aplikasinya di Indonesia Bagian I. Bogor (ID): Departemen Ilmu Ekonomi, Institut Pertanian Bogor. Ricky, Rinaldi. 2014. Analisis Daya Saing dan Faktor-Faktor yang Mempengaruhi Aliran Perdagangan Komoditi Unggulan Ekspor Indonesia ke Afrika Selatan. [Tesis]. Program Pascasarjana, Institut Pertanian Bogor, Bogor.
Rizka Suci Rahmadhani. 2017.Analisis Potensi Ekspor Ikan Sarden Indonesia di Negara-Negara Afrika Periode Tahun 2010 sampai 2014. [Tesis]. Program Pascasarjana, Institut Pertanian Bogor, Bogor.

Simatupang, P.1991. The Conception of Domestic Resource Cost and Net Economic Benefit for Comparative Advantage Analysis Agribusiness. Division Working Paper. 2:91.

Stolovitch, Harold, D. dan Keeps, E.J. 1992. Handbook of Human Performance Technology A Comprehensive Guide for Analysis and Solving Performance Problem in Organizations. San Francisco: Jersey-Bass Publisher

WITS (World Intregated Trade Solution). 2017. World Development Indicators. http://www.wits.worldbank.org. [ Januari 2017]. 